\title{
Hubungan Kecerdasan Emosional Dengan Leadership Skill Ditinjau Dari Perbedaan Gender Siswa Kelas V
}

\author{
Aulia Deviana Purnamayani ${ }^{1 *}$, Ignatius I Wayan Suwatra², I Made Citra Wibawa ${ }^{3}$ iD \\ ${ }^{1,3}$ Prodi Pendidikan Guru Sekolah Dasar, Universitas Pendidikan Ganesha, Singaraja, Indonesia \\ ${ }^{2}$ Prodi Jurusan Teknologi Pendidikan, Universitas Pendidikan Ganesha, Singaraja, Indonesia \\ *Corresponding author: aulia98.id@ gmail.com
}

\begin{abstract}
Kecerdasan emosional yang masih rendah dimiliki oleh pemimpin laki-laki di SD maka, dilakukan penelitian yang menyangkut hubungan kecerdasan emosional dengan leadership skill. Penelitian ini bertujuan untuk melihat hubungan kecerdasan emosional dengan leadership skill ditinjau dari perbedaan gender pada siswa kelas V di SD. Jenis penelitian ini adalah penelitian ex post facto tipe korelasional. Populasi penelitian ini adalah seluruh siswa kelas V SD sebanyak 138 orang. Sampel ditentukan menggunakan teknik proportional random sampling dan terpilih sebanyak 55 siswa laki-laki dan 55 siswa perempuan dengan total keseluruhan 110 siswa. Data yang dikumpulkan adalah kecerdasan emosional dan leadership skill siswa menggunakan instrument kuesioner. Data dianalisis dengan analisis regresi sederhana dan korelasi product moment. Hasil yang didapat menunjukkan: Terdapat hubungan yang signifikan antara kecerdasan emosional dan leadership skill dengan koefisien determinasi sebesar $44.3 \%$ dan sisanya 55.7\%. sebesar 85.959 > sebesar 3.079 yang berarti terdapat hubungan yang positif dan signifikan antara kecerdasan emosional dengan leadership skill ditinjau dari perbedaan gender pada siswa kelas V.
\end{abstract}

Keywords: Kecerdasan Emosional, Leadership Skill, Gender

\begin{abstract}
Male leaders in elementary school had low emotional intelligence, so research was conducted on the relationship between emotional intelligence and leadership skills. This study aims to see the relationship between emotional intelligence and leadership skills in terms of gender differences in fifth grade students in elementary school. This research type is ex post facto correlational type. The population of this study were all students of grade V SD in Gugus X, Buleleng District, Buleleng Regency, as many as 138 people. The sample was determined using proportional random sampling technique and selected 55 male students and 55 female students with a total of 110 students. The data collected were students' emotional intelligence and leadership skills using a questionnaire instrument. Data were analyzed by simple regression analysis and product moment correlation. The results obtained indicate: There is a significant relationship between emotional intelligence and leadership skills with a determination coefficient of $44.3 \%$ and the remaining 55.7\%. of 85,959> 3,079, which means that there is a positive and significant relationship between emotional intelligence and leadership skills in terms of gender differences in grade V students at SD Gugus X, Buleleng District.
\end{abstract}

Keywords: Emotional Intelligence, Leadership Skill, Gender

$\begin{array}{lll}\text { History: } & \text { Publisher: Undiksha Press } \\ \text { Received } & : 24 \text { Mei } 2020 & \text { Licensed: This work is licensed under } \\ \text { Revised } & : \text { Juni } 2020 & \text { a Creative Commons Attribution 3.0 License } \\ \text { Accepted } & : 6 \text { Juli } 2020 & \text { CC } \\ \text { Published }: 30 \text { October } 2020 & \end{array}$




\section{Introduction}

Setiap orang memiliki kedudukan dan hak yang sama dalam mengembangkan kemampuan serta keterampilannya, tidak terkecuali bagi kaum perempuan. Hal senada juga disampaikan Puspitawati (2013), yaitu perempuan dan laki-laki menikmati status yang setara dan memiliki kondisi yang sama untuk mewujudkan secara penuh hak-hak asasi dan potensinya bagi pembangunan di segala bidang kehidupan. Namun realitanya, jumlah perempuan yang menduduki posisi sebagai pimpinan masih sangat jauh dibandingkan dengan laki-laki. Menurut data PBB tahun 2015, perempuan hanya mengemban satu per sepuluh jumlah pemimpin dunia saat ini dari negara-negara anggota PBB (Quamila, 2020). Selain itu, menurut Badan Pusat Statistik (BPS) masih adanya kesenjangan antara laki-laki dan perempuan dalam iklim ketenagakerjaan Indonesia. Berdasarkan jenis kelaminnya, Tingkat Partisipasi Angkatan Kerja (TPAK) laki-laki pada Agustus 2018 tercatat sebesar 82,69\%, sedangkan TPAK perempuan hanya sebesar 51,88\% (Andreas, 2018). Lebih lanjut, hasil survei Politica Research Consulting (PRC) dan Parameter Politik Indonesia menunjukan, peluang perempuan menjadi kandidat dalam Pemilihan Presiden 2024, yaitu hanya 7,2\% dan $72,2 \%$ responden lebih setuju laki-laki menjadi pemimpin nasional, sementara 20,6 persen responden tidak memberikan jawaban (Handayani, 2020). Selanjutnya, hasil penelitian Herlina, H., \& Muhyani (2018) mengenai jiwa kepemimpinan, siswa laki-laki masih mendominasi kedudukan sebagai pemimpin. Berdasarkan beberapa hasil survie dan hasil penelitian di atas menunjukan bahwa perbedaan gender masih sangat berpengaruh dalam hal memilih pemimpin.

Secara terminologi, gender dapat didefinisikan sebagai harapan budaya terhadap lakilaki dan perempuan. Sehingga gender dipandang sebagai suatu konsep kultural yang dipakai untuk membedakan peran, perilaku, mentalitas, dan karakteristik emosional antara laki-laki dan perempuan yang berkembang dalam masyarakat. Menurut Fazlurrachman (dalam Purwanti, 2013) istilah gender diketengahkan oleh para ilmuwan sosial untuk menjelaskan perbedaan perempuan dan laki-laki yang bersifat bawaan sebagai ciptaan Tuhan yang merupakan bentukan budaya yang dikonstruksikan, dipelajari dan disosialisasikan. Selanjutnya, Arianti (2019) dan Nurmasari, dkk (dalam Anggoro, 2016) menyatakan gender adalah perbedaan antara laki-laki dan perempuan dalam hal peran, fungsi, perilaku yang sesuai dengan tata nilai yang berlaku dalam masyarakat. Berdasarkan pengamatan yang dilakukan pada tanggal 24-31 Oktober 2019 di Sekolah Dasar di Gugus X Kecamatan Buleleng dapat dilihat bahwa anak laki-laki masih mendominasi kedudukan sebagai pemimpin, seperti yang tertera pada Tabel 1.

Tabel 1. Data Jumlah Siswa dan Ketua Kelas V SD Gugus X Kecamatan Buleleng

\begin{tabular}{|c|c|c|c|c|c|}
\hline \multirow{2}{*}{ No. } & \multirow{2}{*}{ Nama Sekolah } & \multicolumn{2}{|c|}{ Jumlah Siswa } & \multirow{2}{*}{ Total } & \multirow{2}{*}{ Ketua Kelas } \\
\hline & & Laki-laki & Perempuan & & \\
\hline 1. & SD No. 1 Kaliuntu & 9 & 13 & 22 & $\mathrm{P}$ \\
\hline 2. & SD No. 2 Kaliuntu & 15 & 5 & 20 & $\mathrm{~L}$ \\
\hline 3. & SD No. 3 Kaliuntu & 12 & 13 & 25 & $\mathrm{~L}$ \\
\hline 4. & SD No. 4 Kaliuntu & 19 & 18 & 37 & $\mathrm{~L}$ \\
\hline 5. & SD Katolik Karya Singaraja & 18 & 16 & 34 & $\mathrm{P}$ \\
\hline & Total & 73 & 65 & 138 & - \\
\hline
\end{tabular}

Kecenderungan guru memilih siswa laki-laki sebagai ketua kelas bukan semata-mata karena siswa tersebut pandai di kelasnya, atau lebih aktif daripada siswa lainnya, namun juga karena guru ingin siswa tersebut belajar untuk menjadi pemimpin walaupun tidak menonjol dalam bidang apapun. Kristianto, A. A., \& Fitriana (2019) mengatakan bahwa kepemimpinan seseorang dapat dibentuk, caranya adalah dengan memberikan kesempatan luas kepada yang bersangkutan untuk menumbuhkan dan mengembangkan efektivitas kepemimpinannya 
melalui berbagai kegiatan pendidikan dan latihan kepemimpinan. Sementara itu, menurut Kartono (dalam Oktiani, E., Hanifah, N., \& Aeni, 2017) jiwa kepemimpinan hendaknya ditanamkan sejak dini dalam diri individu dan didukung oleh lingkungan sekitar seperti keluarga, sekolah, maupun teman bermain. Berdasarkan pernyataan tersebut sekolah merupakan tempat siswa menimba ilmu, baik dalam hal pengetahuan maupun mengembangkan keperibadian, salah satunya mengembangkan jiwa kepemimpinan.

Kepemimpinan (leadership skill) merupakan kemampuan atau kecerdasan mendorong sejumlah orang (dua orang atau lebih) agar bekerjasama dalam melaksanakan kegiatankegiatan yang terarah pada tujuan bersama (Kuswara, R., Hartuti \& Sinthia, 2018). Dimyati (2014:33) mendefinisikan "kepemimpinan merupakan suatu masalah yang kompleks dan sulit karena sifat dasar kepemimpinan memang sangat kompleks. Kepemimpinan melibatkan hubungan pengaruh yang mendalam antar orang yang menginginkan perubahan yang mencerminkan tujuan yang dimiliki bersama oleh pemimipin dan pengikutnya". Sementara itu, Marpaung (2014) mendefinisikan kepemiminan sebagai tatanan tingkah laku yang dirancang untuk mengintegrasikan tujuan individu untuk mencapai tujuan tertentu, proses untuk mempengaruhi orang lain untuk memahami dan setuju dengan apa yang perlu dilakukan dan bagaimana tugas itu dilakukan secara efektif, serta proses untuk menfasilitasi upaya individu dan kolektif untuk mencapai tujuan bersama. Lebih lanjut, Farida \& Anjani (2019) menjelaskan kepemimpinan merupakan sifat-sifat kepribadian seseorang yang meliputi, pengetahuan, kewibawaan, serta kemampuan untuk menggerakan orang lain sehingga mau melaksanakan tugas yang dibebankan kepadanya dengan suka rela dan ikhlas. Jadi, kepemimpinan dapat diartikan suatu kemampuan seseorang dalam mengarahkan sejumlah orang untuk mencapai tujuan bersama. Seseorang yang memiliki leadership skill tentunya harus didukung oleh moral, disiplin, jiwa korsa dan kecakapan dalam melaksanakan tugas dengan hasil yang baik dalam waktu yang efisien Dimyati (2014). Mumford, T. V., Campion \& Morgeson, (2007) juga berpendapat bahwa kompetensi kepemimpinan seperti komunikasi, kerja tim, dan keterampilan pribadi dan interpersonal dianggap penting bagi para pemimpin serta kefleksibilitasan dalam pengambilan keputusan, keterampilan menyimak yang baik, dan gaya pemecahan masalah juga harus dimiliki oleh seoarang pemimpin.

Menjadi seorang pemimpin tidak hanya harus memiliki kecerdasan intelektual yang tinggi melainkan harus mampu mengendalikan emosi dengan baik sehingga dapat memahami perasaan diri sendiri maupun orang lain serta memiliki kepekaan yang tinggi. Senada dengan hal tersebut, Estining (dalam Rahmasari, 2012) menjelaskan, seorang pemimpin hendaknya memiliki kecerdasan emosional yang tinggi karena pemimpin akan menjadi panutan bagi anggotanya dalam berbagai hal, misalnya saja dalam berinteraksi ataupun menjalin hubungan dengan orang lain. Marhaeni (dalam Setyawan, A. A., \& Simbolon 2018) mendefinisikan kecerdasan emosional adalah kemampuan merasakan, memahami, dan secara efektif menerapkan daya dan kepekaan emosi sebagai sumber energi, informasi, koneksi dan pengaruh yang manusiawi. Lebih lanjut dijelaskan, bahwa kecerdasan emosi menuntut seseorang untuk belajar mengakui, menghargai perasaan diri sendiri dan orang lain. Sementara menurut Rahmasari (2012) kecerdasan emosional adalah kemampuan seseorang untuk mengenali emosi diri, mengelola emosi, memotivasi diri sendiri, mengenali emosi orang lain (empati) dan kemampuan untuk membina hubungan (kerjasama) dengan orang lain. Lebih lanjut, Daud (2012) mendefinisikan, kecerdasan emosi (EQ) merupakan karakteristik seseorang sebagai suatu jenis kecerdasan yang amat perlu ditingkatkan. EQ merupakan penggerak yang dapat menimbulkan aspek-aspek energi, kekuatan, daya tahan, dan stamina. Jadi, kecerdasan emosional dapat didefinasikan sebagai kemampuan merasakan, memahami dan secara selektif menerapkan daya dan kepekaan emosi sebagai sumber energi dan pengaruh yang manusiawi dari seorang siswa dengan adanya kecerdasan emosional yang tinggi dari siswa maka dapat menuntut siswa untuk mengakui, menghargai perasaan pada diri 
sendiri dan orang lain serta menanggapinya dengan tepat, menerapkan secara efektif energi emosi dalam kehidupan sehari-hari terutama dalam sekolahnya.

Menurut Rivai (2004) menyatakan ada beberapa sifat yang juga diidentifikasi berhubungan dengan kepemimpinan, yaitu meliputi: 1) kecerdasan; 2) kemampuan untuk bergaul dengan orang lain; 3) keterampilan teknik dalam bidangnya; 4) kemampuan untuk memotivasi diri sendiri dan orang lain; 5) kestabilan emosi dan kontrol pribadi; 6) keterampilan perencanaan dan pengorganisasian serta keinginan yang kuat untuk menyelesaikan pekerjaan; 7) kemampuan untuk menggerakkan kelompok; 8) kemampuan untuk berbuat efektif dan efisien; setra 9) tegas. Kecerdasan emosional secara tak langsung mempengaruhi kemampuan seseorang untuk menjadi pemimpin (leadership skill). Hasil penelitian Supriyanto, A. S., \& Troena (2012); Budiono, B., \& Wibowo (2014); Utami (2014) menunjukan adanya hubungan kecerdasan emosional dan kemampuan memimpin seseorang. Semakin tinggi kecerdasan emosional seseorang, maka semakin baik pula kepemimpinannya. Lebih lanjut, menurut Saputra (2010) tujuan suatu organisasi akan tercapai dengan optimal apabila seorang pemimpin memiliki kecerdasan emosional dan spiritual yang seimbang.

Berdasarkan pemaparan di atas, penelitian ini bertujuan untuk meninjau hubungan yang positif dan signifikan antara kecerdasan emosional dengan leadership skill ditinjau dari perbedaan gender pada siswa kelas V di SD. Perbedaan penelitian ini dengan penelitian sejenis adalah meninjau hubungan kecerdasan emosional dengan leadership skill dari perbedaan gender.

\section{Materials and Methods}

Jenis penelitian yang digunakan adalah penelitian expost facto dengan menggunakan pendekatan kuantitatif (Mahendra, 2017). Rancangan penelitian ini adalah penelitian deskripsi korelasional. Peneliti mencari hubungan antara variable $\mathrm{X}$, yaitu kecerdasan emosional dengan variabel $\mathrm{Y}$, yaitu leadership skill yang ditinjau oleh variabel $\mathrm{Z}$, yaitu perbedaan gender siswa. Dalam penelitian ini peneliti bermaksud meneliti hubungan kecerdasan emosional dengan leadership skill ditinjau dari perbedaan gender siswa. Penelitian ini dilakukan di Sekolah Dasar di Gugus X Kecamatan Buleleng Kabupaten Buleleng. Adapun waktu pelaksanaan penelitian yaitu pada tanggal 10 Februari - 14 Maret 2020.

Populasi pada penelitian ini adalah seluruh siswa kelas V SD di Gugus X Kecamatan Buleleng tahun ajaran 2019/2020 yang digunakan sebagai populasi adalah siswa dari SD No. 1 Kaliuntu, SD No. 2 Kaliuntu, SD No. 3 Kaliuntu, SD No. 4 Kaliuntu, dan SD Katolik Karya Singaraja. Jumlah populasi keseluruhan adalah 138 siswa dengan komposisi pada masing-masing sekolah disajikan pada Tabel 2.

Tabel 2. Jumlah Populasi Siswa Kelas V SD di Gugus X Kecamatan Buleleng

\begin{tabular}{|c|c|c|c|c|}
\hline \multirow{2}{*}{ No } & \multirow{2}{*}{ Nama Sekolah } & \multicolumn{2}{|c|}{ Jumlah Siswa } & \multirow{2}{*}{$\begin{array}{c}\text { Jumlah Siswa } \\
\text { Seluruhnya }\end{array}$} \\
\hline & & Laki-laki & Perempuan & \\
\hline & SD No. 1 Kaliuntu & 9 & 13 & 22 \\
\hline & SD No. 2 Kaliuntu & 15 & 5 & 20 \\
\hline & SD No. 3 Kaliuntu & 12 & 13 & 25 \\
\hline & SD No. 4 Kaliuntu & 19 & 18 & 37 \\
\hline & SD Katolik Karya Singaraja & 18 & 16 & 34 \\
\hline & Total Populasi & 73 & 65 & 138 \\
\hline
\end{tabular}

Sampel diambil dengan cara proportional random sampling (berimbang secara acak) untuk menentukan proporsi pengambilan sampel digunakan jumlah sampel laki-laki dan perempuan dengan teknik penentuan sampel menurut Willam G. Cochran. 
Berdasarkan rumus tersebut, maka diperoleh persentase siswa laki-laki untuk tiap sekolah diambil sebesar $75.34 \%$ dari jumlah siswa laki-laki dan persentase siswa perempuan untuk tiap sekolah yang diambil sebesar $84.62 \%$ dari jumlah siswa pertemuan yang ada tiap sekolah. Perhitungan persentase sampel dari populasi disajikan pada Tabel 3.

Tabel 3. Jumlah Sampel Siswa Kelas V SD di Gugus X Kecamatan Buleleng

\begin{tabular}{|c|c|c|c|c|}
\hline \multirow[b]{2}{*}{ No. } & \multirow[b]{2}{*}{ Nama Sekolah } & \multicolumn{2}{|c|}{ Jumlah Siswa } & \multirow[b]{2}{*}{$\begin{array}{c}\text { Jumlah Siswa } \\
\text { Seluruhnya }\end{array}$} \\
\hline & & $\begin{array}{l}\text { Laki-laki } \\
(75,34 \%)\end{array}$ & $\begin{array}{c}\text { Perempuan } \\
(84,62 \%)\end{array}$ & \\
\hline 1. & SD No. 1 Kaliuntu & 7 & 11 & 18 \\
\hline 2. & SD No. 2 Kaliuntu & 11 & 4 & 15 \\
\hline 3. & SD No. 3 Kaliuntu & 9 & 11 & 20 \\
\hline 4. & SD No. 4 Kaliuntu & 14 & 15 & 29 \\
\hline 5 & SD Katolik Karya Singaraja & 14 & 14 & 28 \\
\hline & Total Sampel & 55 & 55 & 110 \\
\hline
\end{tabular}

Penelitian ini memiliki dua variabel yang terdiri dari variabel bebas, variabel terikat dan variable rambang. Variabel bebasnya yaitu kecerdasan emosional siswa, sedangkan variabel terikatnya Leadership skill siswa dan variable rambangnya yaitu perbedaan gender siswa. Teknik pengumpulan data yang digunakan yaitu dengan observasi dan memberikan angket (kuesioner) untuk mengetahui kecerdasan emosional dan leadership skill siswa. Instrumen yang digunakan untuk mengumpulkan data kecerdasan emosional dan leadership skill siswa adalah angket (kuesioner). Angket (kuesioner) ini disajikan dalam bentuk skala Likert lima alternatif jawaban, sehingga responden tinggal memberi tanda centang $(\sqrt{ })$ pada jawaban yang tersedia. Adapun kisi-kisi yang dikembangkan berdasarkan pendapat dari Dimyati (2014) \& Komarudin (2016) yaitu untuk kecerdasan emosional terdiri dari beberapa indikator yang diteliti, yaitu; (1) kesadaran diri (self-awareness), (2) pengaturan diri (selfregulation), (3) memotivasi diri sendiri maupun orang lain, (4) mengenali emosi orang lain, dan (5) keterampilan dalam membina hubungan sosial (orang lain maupun sesama siswa). Kecerdasan emosional siswa adalah skor yang didapat setelah siswa menjawab kuesioner dengan pernyataan positif (favourable) yang terdiri dari 13 item dan pernyataan negatif (unfavourable) terdiri dari 12 item, sehingga jumlah pernyataan terdiri dari 25 item. Sedangkan Leadership skill terdiri dari beberapa indikator yang diteliti pada penelitian ini, yaitu; (1) keterampilan berkomunikasi, (2) kemampuan mempengaruhi orang lain, (3) percaya diri, (4) kecerdasan berfikir dan emosi, serta (5) dorongan yang kuat dari dalam untuk memimpin. Leadership skill siswa adalah skor yang didapat setelah siswa menjawab angket (kuesioner) dengan pernyataan positif (favourable) yang terdiri dari 11 item dan pernyataan negatif (unfavourable) terdiri dari 9 item, sehingga jumlah pernyataan terdiri dari 20 item.

Sebelum instrumen digunakan, perlu dilakukan pengujian instrument dengan 2 uji yaitu uji pakar dari hasil perhitungan diperoleh 25 butir pernyataan untuk instrumen kecerdasan emosional siswa, sedangkan instrumen leadership skill siswa yaitu 20 butir pernyataan. Pada uji validitas menggunakan formula KR-21 pada kuesioner kecerdasan emosional diperoleh dari 25 butir pernyataan dapat digunakan 20 butir saja, untuk butir nomor $7,11,12,22$, dan 25 dinyatakan tidak valid, sedangkan pada kuesioner leadership skill, 20 butir pernyataan dapat digunakan 16 butir saja, untuk butir nomor 5, 6, 14, dan 15 dinyatakan tidak valid. Uji reliabilitas pada kecerdasan emosional berada pada kategori reliabilitas sangat tinggi karena hasil perhitungan yang didapat 0,8239 , sedangkan untuk instrumen leadership skill hasil perhitungan reliabilitas yang didapat 0,7962 sehingga berada pada kategori reliabilitas tinggi.

Metode analisis data yang digunakan dalam penelitian ini adalah metode analisis statistik deskriptif dan analisis statistik inferensial. Adapun langkah-langkah analisis statistik 
deskriptif pada data yaitu melalui pemberian skor, mencari kelas tinggi dan kelas rendah, menentukan jumlah kelas, menghitung panjang kelas interval, dan membuat tabel distribusi frekuensi. Sedangkan metode analisis statistik inferensial yang digunakan dalam penelitian ini terdiri dari uji prasyarat analisis (diantarnya menggunakan uji normalitas data (kolmogorov-smirnov) dan uji linarites data) dan uji hipotesis. Untuk menguji hipotesis penelitian dilakukan analisis data dengan menggunakan teknik analisis regresi sederhana atau korelasi product moment yang digunakan untuk menentukan signifikansi korelasi antara variabel terikat $(\mathrm{Y})$ dan satu variabel bebas $(\mathrm{X})$. Adapun langkah-langkah yang dilakukan untuk menguji hipotesis dalam penelitian ini yaitu dengan mencari korelasi $\mathrm{X}$ dengan $\mathrm{Y}$ melalui teknik korelasi product moment $\left(R_{x y}\right)$ dari Pearson, mencari besar koefisien korelasi, menguji signifikansi korelasi, mencari persamaan garis regresi, dan menentukan koefisien determinasi.

\section{Results and Discussion}

Deskripsi data penelitian ini adalah deskripsi data kecerdasan emosional dan deskripsi data leadership skill. Deskripsi data kecerdasan emosional diperoleh dari data kuesioner kecerdasan emosional siswa laki-laki dan siswa perempuan. Berdasarkan analisis deskripsi data kecerdasan emosional, diperoleh hasil yang akan disajikan pada Tabel 4.

Tabel 4. Deskripsi Data Kecerdasan Emosional Siswa Laki-laki dan Perempuan

\begin{tabular}{ccc}
\hline \multirow{2}{*}{ Kategori } & Laki-laki & Perempuan \\
\cline { 2 - 3 } & Total siswa yang memperoleh & Total siswa yang memperoleh \\
\hline Sangat Baik & 7 & 14 \\
\hline Baik & 44 & 37 \\
\hline Cukup & 4 & 4 \\
\hline Rendah & 0 & 0 \\
\hline Rendah Sekali & 0 & 0 \\
\hline $\begin{array}{c}\text { Rata-rata skor kecerdasan } \\
\text { emosional }\end{array}$ & 71,65 & 74,4 \\
\hline
\end{tabular}

Berdasarkan tabel di atas, diketahui bahwa pada kelompok siswa laki-laki terdapat 7 orang memperoleh kategori skor kecerdasan emosional sangat baik, 44 orang baik, 4 orang cukup. Sedangkan pada siswa perempuan terdapat 14 orang memiliki kategori kecerdasan emosional sangat baik, 37 orang baik, dan 4 orang cukup. Rata-rata kecerdasan emosional siswa laki-laki sebesar 71,65 dengan kategori baik sedangkan siswa perempuan memiliki rata-rata kecerdasan emosional sebesar 74,4 dengan kategori baik.

Selanjutnya, berdasarkan analisis deskripsi data leadership skill, diperoleh hasil yang akan ddisajikan pada Tabel 5 .

Tabel 5. Deskripsi Data leadership skill Siswa Laki-laki dan Perempuan

\begin{tabular}{ccc}
\hline \multirow{2}{*}{ Kategori } & Laki-laki & Perempuan \\
\cline { 2 - 3 } & Total siswa yang memperoleh & Total siswa yang memperoleh \\
\hline Sangat Baik & 0 & 0 \\
\hline Baik & 27 & 32 \\
\hline Cukup & 28 & 22 \\
\hline Rendah & 0 & 1 \\
\hline Rendah Sekali & 0 & 0 \\
\hline Rata-rata skor leadership skill & 60,53 & 62,72 \\
\hline
\end{tabular}

Berdasarkan Tabel 5, diketahui bahwa pada kelompok siswa laki-laki terdapat 27 orang memperoleh kategori skor leadership skill baik, 28 orang cukup. Sedangkan pada siswa perempuan terdapat 32 orang memiliki kategori leadership skill baik, 32 orang cukup, 
dan 1 orang rendah. Rata-rata kecerdasan emosional siswa laki-laki sebesar 60,53 dengan kategori cukup sedangkan siswa perempuan memiliki rata-rata kecerdasan emosional sebesar 62,72 dengan kategori baik.

Setelah dilakukan analisis deskriptif data dilanjutkan dengan uji normalitas. Hasil uji normalitas sebaran data yaitu diperoleh hasil perhitungan menggunakan rumus explore kolmogorov-smirnov dengan bantuan SPSS 26 for windows. Adapun kriteria pengujian jika signifikansi > 0.05, maka $\mathrm{H}_{0}$ diterima dan data berdistribusi normal, sedangkan jika signifikansi $<0.05$, maka $\mathrm{H}_{0}$ ditolak dan data tidak berdistribusi normal. Pada analisis yang telah dilakukan, pada Tabel 6. disajikan hasil uji coba sebaran data dengan bantuan SPSS seperti pada Tabel 6 .

Tabel 6. Hasil Uji Normalitas Kecerdasan Emosional Siswa dan Leadership Skill Siswa

\begin{tabular}{|c|c|c|c|c|c|c|c|}
\hline & & \multicolumn{3}{|c|}{ Kolmogorov-Smirnova } & \multicolumn{3}{|c|}{ Shapiro-Wilk } \\
\hline & & Statistik & df & Sig. & Statistik & Df & Sig. \\
\hline \multirow{2}{*}{$\begin{array}{c}\text { Kecerdasan } \\
\text { Emosional }\end{array}$} & Laki-laki & .093 & 55 & $.200^{*}$ & .981 & 55 & .552 \\
\hline & Perempuan & .073 & 55 & $.200^{*}$ & .982 & 55 & .586 \\
\hline \multirow{2}{*}{ Leadership Skill } & Laki-laki & .082 & 55 & $.200 *$ & .986 & 55 & .788 \\
\hline & Perempuan & .111 & 55 & $.200 *$ & .969 & 55 & .482 \\
\hline
\end{tabular}

Berdasarkan hasil perhitungan menggunakan rumus kolmogorov-smirnov dengan bantuan SPSS 26 for windows, data hasil kuesioner kecerdasan emosional siswa laki-laki dan perempuan yaitu $0.200>0.05$ yang berarti data berdistribusi normal. Sedangkan pada hasil uji normalitas leadership skill siswa menggunakan rumus Kolmogorov smirnov dengan bantuan SPSS 26 for windows, data hasil kuesioner leadership skill siswa laki-laki dan perempuan yaitu $0.200>0.05$ yang berarti data berdistribusi normal.

Hasil uji linearities dengan kriteria signifikansi deviation from linearity lebih besar dari 0.05 , maka antara variabel bebas dan variabel terikat memiliki hubungan yang berarti. Berdasarkan perhitungan uji linearities diperoleh signifikansi Linearity sebesar 0.000 $(\mathrm{p}<0.05)$ sehingga kecerdasan emosional dengan leadership skill memiliki hubungan yang linier, Sedangkan signifikansi Deviation from Linearity sebesar $0.154(\mathrm{p}>0.05)$ sehingga kecerdasan emosional dengan leadership skill memiliki hubungan yang berarti dapat dilihat pada Tabel 7.

Tabel 7. Hasil Uji Linearities dan Uji Korelasi Kecerdasan Emosional dengan Leadership Skill

\begin{tabular}{|c|c|c|c|c|c|c|c|}
\hline & & & Jumlah & $\mathrm{df}$ & Rata-rata & $\mathrm{F}$ & Sig. \\
\hline \multirow{5}{*}{$\begin{array}{c}\text { Leadership } \\
\text { Skill * } \\
\text { Kecerdasan } \\
\text { Emosional }\end{array}$} & \multirow{3}{*}{$\begin{array}{c}\text { Antar } \\
\text { Kelompok }\end{array}$} & (Combined) & 4203.902 & 32 & 131.372 & 4.241 & .000 \\
\hline & & Linearity & 2920.206 & 1 & 2920.206 & 94.269 & .000 \\
\hline & & $\begin{array}{c}\text { Deviation from } \\
\text { Linearity }\end{array}$ & 1283.696 & 31 & 41.410 & 1.337 & .154 \\
\hline & \multicolumn{2}{|c|}{ Dalam Kelompok } & 2385.270 & 77 & 30.978 & & \\
\hline & \multicolumn{2}{|c|}{ Total } & 6589.173 & 109 & & & \\
\hline & & & \multicolumn{2}{|c|}{$\begin{array}{c}\text { Kecerdasan } \\
\text { Emosional }\end{array}$} & \multicolumn{3}{|c|}{ Leadership Skill } \\
\hline \multirow{3}{*}{\multicolumn{2}{|c|}{ Kecerdasan Emosional }} & Korelasi Pearson & \multicolumn{2}{|c|}{1} & \multicolumn{3}{|c|}{$.666^{* *}$} \\
\hline & & Sig. (2-tailed) & & & \multicolumn{3}{|c|}{.000} \\
\hline & & $\mathrm{N}$ & \multicolumn{2}{|c|}{110} & \multicolumn{3}{|c|}{110} \\
\hline \multirow{3}{*}{\multicolumn{2}{|c|}{ Leadership Skill }} & Korelasi Pearson & \multicolumn{2}{|c|}{$.666^{* *}$} & \multicolumn{3}{|c|}{1} \\
\hline & & Sig. (2-tailed) & \multicolumn{2}{|c|}{.000} & \\
\hline & & $\mathrm{N}$ & \multicolumn{2}{|c|}{110} & \multicolumn{3}{|c|}{110} \\
\hline
\end{tabular}


Berdasarkan Tabel 7, dapat disimpulkan bahwa ada hubungan linier dan berarti secara signifikan antara variabel kecerdasan emosional (X) dengan variabel leadership skill (Y). Pada hasil uji hipotesis yaitu diawali dengan uji korelasional product moment bertujuan untuk membuktikan adanya hubungan yang signifikan antara kecerdasan emosional dengan leadership skill siswa. Penjelasan hasil analisis korelasi dengan menggunakan rumus korelasi product moment $\left(\mathrm{r}_{\mathrm{xy}}\right)$ adalah sebagai berikut.

Berdasarkan hasil uji korelasi tersebut, diperoleh hasil signifikasi sebesar $0,000<$ 0,05 , yang artinya terdapat korelasi antara variabel kecerdasan emosional dengan variabel leadership skill. Berdasarkan nilai $r_{\text {hitung }}$ (Person Correlation) diketahui $\mathrm{r}_{\text {hitung }}$ untuk hubungan kecerdasan emosional $(\mathrm{X})$ dengan leadership skill $(\mathrm{Y})$ adalah sebesar $0.666>\mathrm{r}_{\text {tabel }} 0.187$, maka dapat disimpulkan bahwa ada hubungan atau korelasi antara variabel kecerdasan emosional dengan leadership skill. Karena $\mathbf{r}_{\text {hitung }}$ atau Pearson correlation dalam analisis ini bernilai positif maka itu artinya hubungan antara kedua variabel tersebut bersifat positif atau dengan kata lain semakin meningkatnya kecerdasan emosional maka akan meningkat pula leadership skill siswa. Koefisien korelasi yang diperoleh yaitu sebesar 0.666. Apabila disesuaikan dengan kriteria korelasi nilai $r$ diperoleh hasil koefisien korelasi berada pada interval 0.60 sampai 0.799 dengan kategori kuat.

Hasil uji signifikansi korelasi diperoleh nilai $F_{\text {hitung }}$ sebesar $85.959>F_{\text {tabel }}$ sebesar 3.079 dan untuk mencari persamaan regresi dilakukan dengan rumus $\hat{Y}=a+b X$ sehingga diperoleh hasil $\mathrm{a}=17.181$, sedangkan $\mathrm{b}=0.609$. Jadi persamaan regresinya adalah $\hat{Y}=a+b X$ $=17.181+0.609 \mathrm{X}$. Koefisien regresi variabel kecerdasan emosional $(\mathrm{X})$ sebesar 0.609. Persamaan regresi dengan rumus $\hat{Y}=a+b X$ akan disajikan kedalam diagram garis seperti gambar 1 berikut.

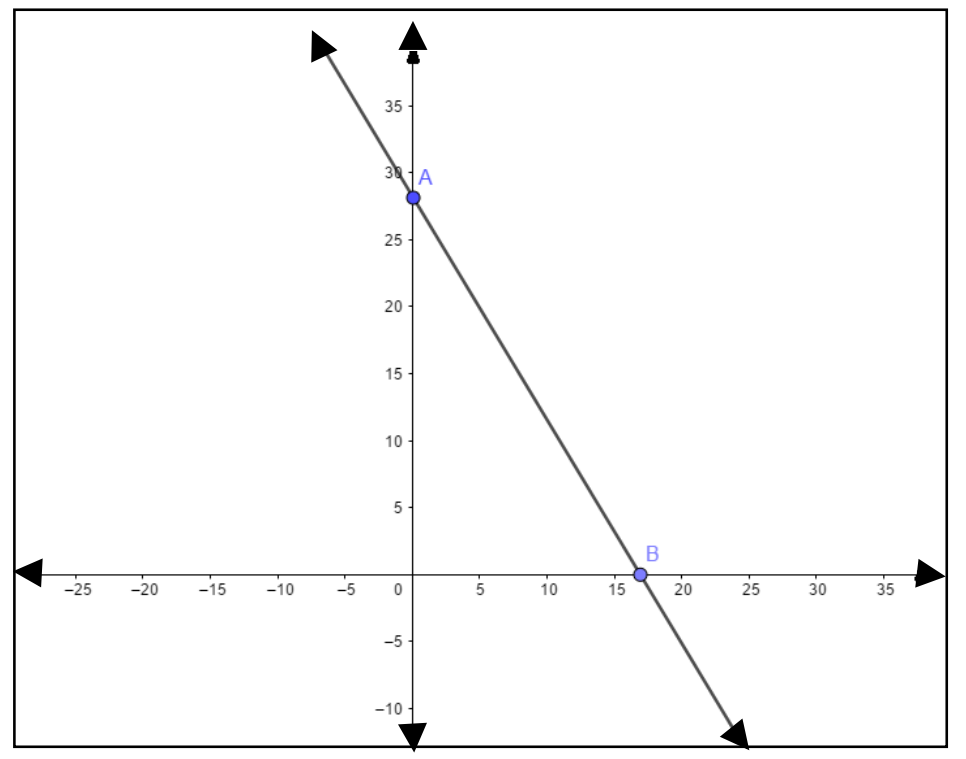

Gambar 1. Diagram Garis Korelasi Kecerdasan Emosional dan leadership skill

Berdasarkan gambar 1, dapat diketahui bahwa peningkatan 1 skor variabel kecerdasan emosional dengan asumsi variabel bebas lain konstan akan menyebabkan kenaikan leadership skill sebesar 0.609. Diketahui bahwa nilai koefisien determinasi atau $\mathrm{R}$ square adalah sebesar 0.443 atau sama dengan $44.3 \%$. Angka tersebut mengandung makna bahwa variabel kecerdasan emosional (X) berpengaruh terhadap variabel leadership skill (Y) sebesar $44.3 \%$. Sedangkan sisanya $(100 \%-44.3 \%=55.7 \%)$ dipengaruhi variabel lain diluar persamaan regresi ini atau variabel yang tidak diteliti. Hal ini berarti hipotesis nol $\left(\mathrm{H}_{0}\right)$ ditolak dan hipotesis alternatif $\left(\mathrm{H}_{1}\right)$ diterima. Jadi, dapat disimpulkan bahwa terdapat 
hubungan yang positif dan signifikan antara kecerdasan emosional dengan leadership skill ditinjau dari perbedaan gender siswa kelas V SD di Gugus X Kecamatan Buleleng tahun ajaran 2019/2020.

Berdasarkan deskripsi data hasil penelitian, diketahui bahwa terdapat hubungan yang positif dan signifikan antara kecerdasan emosional dengan leadership skill ditinjau dari perbedaan gender pada siswa kelas V SD di Gugus X Kecamatan Buleleng tahun ajaran 2019/2020. Semakin meningkatnya kecerdasan emosional maka akan meningkat pula leadership skill siswa. Hal ini didukung oleh hasil kecerdasan emosional siswa perempuan yang lebih tinggi dari laki-laki, jika ditinjau dari nilai kecerdasan emosional yang dikonversi berdasarkan kriteria PAP skala lima bahwa 14 siswa perempuan memperoleh nilai kriteria sangat baik dengan rata-rata skor yaitu 74.4 sedangkan siswa laki-laki yang memperoleh nilai kriteria sangat baik yaitu berjumlah 7 siswa dan rata-rata skor nya yaitu 71.65, maka tingkat kecerdasan emosional siswa perempuan lebih tinggi dari siswa laki-laki. Sebanding juga dengan leadership skill siswa perempuan yang lebih tinggi dari laki-laki yang dapat dilihat berdasarkan nilai rata-rata konversi dengan kriteria penilaian acuan patokan (PAP) skala 5 bahwa 32 siswa perempuan memperoleh nilai dangan kriteria baik dan nilai rata-rata skor yaitu 62.72 sedangkan siswa laki-laki memperoleh nilai dengan criteria baik yaitu 27 siswa dan rata-rata skor yaitu 60.53, maka dari itu siswa perempuan memiliki leadership skill yang unggul pula.

Apabila kecerdasan emosional seseorang lebih tinggi akan mempengaruhi leadership skill-nya. Hal tersebut didukung oleh hasil penelitian Agustina \& Hariyadi (2018), yaitu kecerdasan emosional sangat mempengaruhi adanya interaksi sosial. Siswa yang berinteraksi sosial dengan baik akan dapat mengatasi berbagai persoalan di dalam pergaulan sehingga dapa meningkatkan jiwa kepemimpinan. Kecerdasan emosi merupakan kapasitas manusiawi yang dimiliki seseorang dan sangat berguna untuk menghadapi, memperkuat diri, atau mengubah kondisi kehidupan yang tidak menyenangkan menjadi suatu hal yang wajar untuk diatasi (Melianasari, 2016). Terkait bahwa siswa perempuan memiliki nilai kecerdasan emosional yang lebih tinggi maka siswa perempuan yang sebenarnya lebih cocok sebagai seorang pemimpin. Hal ini berkaitan pula dengan karakteristik gender siswa yaitu siswa perempuan yang lebih cenderung memiliki empati dan jiwa sosial yang tinggi, lebih berhatihati dalam menentukan keputusan maupun tindakan sehingga apabila siswa perempuan memimpin rekan-rekannya baik dalam diskusi kelompok maupun mengatur kelas akan sangat terorganisir karena siswa perempuan lebih berhati-hati dalam mengambil sebuah keputusan serta lebih disiplin dibandingkan siswa laki-laki yang cenderung lebih rasional dan pemberani tanpa berfikir panjang dalam mengambil keputusan dan tindakan. Hal ini didukung oleh hasil penelitian oleh Jati \& Yoenanto (2013), diperoleh hasil penelitian yang mengungkapkan bahwa jenis kelamin merupakan salah satu faktor yang dapat mempengaruhi kecerdasan emosional. Hal ini didukung oleh pendapat Santrock (dalam Suryadi \& Nasution, 2019) yaitu gender atau jenis kelamin sangat mempengaruhi sifat dan kepribadian seseorang, begitu juga dengan emosionalnya baik secara langsung maupun tidak langsung. Selain itu, Elliot (dalam Sulistiyawati \& Andriani, 2017); Nugraha, T. H., \& Pujiastuti (2019) menyatakan anak permepuan memiliki kemampuan komunikasi yang lebih unggul dibandikan anak laki-laki. Kemampuan komunikasi sangat penting dimiliki oleh seorang pemimpin.

Untuk memiliki leadership skill yang tinggi tentunya harus memiliki pengendalian emosi yang baik untuk menghindari terjadi perselisihan antara leader dengan anggota dalam kelompoknya. Hal ini sejalan dengan pendapat Goleman (2003) yang mengungkapkan bahwa kecerdasan emosional sebagai suatu kemampuan untuk memotivasi diri sendiri dan bertahan menghadapi frustasi, mengendalikan dorongan hati dan tidak melebih-lebihkan kesenangan, mengatur suasana hati dan menjaga agar beban stress tidak melumpuhkan kemampuan berpikir, berempati dan berdoa. Dalam komponen kecerdasan emosional disebut kesadaran 
diri. Kesadaran diri merupakan dasar kecerdasan emosional yaitu dalam mengetahui perasaan dalam dirinya dan digunakan untuk membuat keputusan bagi diri sendiri (Goleman, 2003). Selain komponen kesadaran diri juga terdapat komponen mengenali emosi orang lain. Individu yang memiliki kemampuan empati lebih mampu menangkap sinyal-sinyal dari luar yang tersembunyi, sehingga ia mampu menerima sudut pandang orang lain, serta lebih mampu untuk mendengarkan. Kemampuan empati ini juga bergantung pada kesadaran emosional diri yang merupakan dasar "keterampilan bergaul", selain itu kemapuan mengindera perasaan seseorang sebab banyak orang yang jarang mengungkapkan persaan mereka lewat kata-kata dan sebaliknya lebih cenderung dengan memberitahukan perasaannya lewat nada suara, ekspresi wajah, atau cara-cara non-verbal lainnya.

Kecerdasan emosional ini menjadi modal untuk kemampuan kepemimpinan siswa. Kepemimpinan yang diperlukan agar mendorong sejumlah orang (dua orang atau lebih) agar bekerjasama dalam melaksanakan kegiatan-kegiatan yang terarah pada tujuan bersama. Untuk dapat mempengaruhi seseorang diperlukan kemampuan pengendalian emosional yang baik. Kepemimpinan seseorang dapat dibentuk, caranya adalah dengan memberikan kesempatan luas kepada yang bersangkutan untuk menumbuhkan dan mengembangkan efektivitas kepemimpinannya melalui berbagai kegiatan pendidikan dan latihan kepemimpinan yang tentunya melibatkan kemampuan pengendalian emosi di dalamnya. Hal ini sejalan dengan pendapat Dimyati (2014) yang menyatakan bahwa seseorang yang memiliki leadership skill tentunya harus didukung oleh moral, disiplin, jiwa korsa dan kecakapan dalam melaksanakan tugas dengan hasil yang baik dalam waktu yang efisien. Beberapa karakter yang harus dimiliki seorang pemimpin menurut Dimyati (2014)yaitu keterampilan komunikasi, kemampuan mempengaruhi orang lain, percaya diri, kecerdasan berpikir (IQ dan EQ), serta dorongan yang kuat dari dalam untuk memimpin. Sedangkan menurut Andy Undap (dalam Herlina, H., \& Muhyani, 2018) ada sejumlah sifat-sifat kepribadian yang perlu dimiliki oleh pemimpin, yaitu, pendidikan yang umum yang luas, kematangan mental, sifat ingin tahu, kemampuan analitis, memiliki daya ingat yang tinggi, intregatif, keterampilan berkomunikasi, keterampilan mendidik, rasional dan objektif, pragmatisme, ada naluri prioritas, pandai mengatur waktu, kesederhanaan, sifat keberanian, dan kemauan mengajar.

Dalam berkomunikasi seseorang perlu memahami emosi orang lain karena setiap orang memiliki karakteristik yang berbeda-beda. Terkadang ada seseorang yang memiliki karakter yang lembut dan tidak suka perkataan yang agak keras, begitu pula sebaliknya ada seseorang yang memiliki karakter yang keras sehingga cenderung menentang atau memberikan kritik yang cukup pedas terhadap suatu kepemimpinan atau ketika melangsungkan sebuah diskusi. Seorang pemimpin yang baik memahami kapan ia harus berbicara tegas kapan harus berbicara yang tenang serta kapan ia harus menerima saran dari orang lain tanpa unsur emosi berlebihan dalam menanggapi kritikan tersebut. Hal tersebutlah yang berkaitan dengan kemampuan mengendalikan emosi atau kecerdasan emosi.

\section{Conclusion}

Berdasarkan hasil penelitian dan pembahasan yang telah disampaikan sebelumnya, maka dapat disimpulkan bahwa terdapat hubungan yang signifikan antara kecerdasan emosional dengan leadership skill ditinjau dari perbedaan gender siswa kelas V SD di Gugus X Kecamatan Buleleng Kabupaten Buleleng Tahun Pelajaran 2019/2020. Adapun saran yang dapat diajukan, yaitu sebagai berikut. Bagi guru, terkait dengan leadership skill (jiwa kepemimpinan) siswa maka dapat disarankan agar guru mampu membina dan melatih jiwa kepemimpinan siswa dengan mengembangkan kecerdasan emosional seperti melatih kemampuan untuk mengontrol emosi dan kemampuan untuk berkomunikasi dengan baik kepada orang lain sehingga siswa mampu memiliki jiwa kepemimpinan yang baik. Kepada 
siswa diharapkan agar lebih memahami dan mengontrol emosi dengan baik serta menumbuhkan rasa tanggung jawab dalam memimpin maupun yang dipimpin. Kepada masyarakat khususnya sebagai orang tua siswa diharapkan dapat memahami dan berpartisipasi mengembangkan kecerdasan emosional anaknya dengan membina anak untuk dapat mengontrol emosi, menumbuhkan rasa tanggung sehingga mereka nantinya memiliki leadership skill.

\section{References}

Agung, A. A. G. (2014). Buku Ajar Metodologi Penelitian Pendidikan. Aditya Media Publishing.

Agustina, R., \& Hariyadi, H. (2018). No Title. AKSIS: Jurnal Pendidikan Bahasa Dan Sastra Indonesia, 2(1), 69-80.

Andreas, D. (2018). Masih Ada Kesenjangan Laki-laki \& Perempuan di Ketenagakerjaan. Tirto.Id. https://tirto.id/bps-masih-ada-kesenjangan-laki-laki-perempuan-diketenagakerjaan-c91R

Anggoro, B. S. (2016). Analisis Persepsi Siswa SMP terhadap Pembelajaran Matematika ditinjau dari Perbedaan Gender dan Disposisi Berpikir Kreatif Matematis. Al-Jabar: Jurnal Pendidikan Matematika, 7(2), 153-166.

Arianti, S. E. Y. (2019). Analisis Kesalahan Peserta Didik Dalam Menyelesaikan Masalah Matematika Berdasarkan Tahapan Newman Ditinjau Dari Perbedaan Gender. Universitas Muhammadiyah Gresik.

Budiono, B., \& Wibowo, U. B. (2014). Pengaruh komunikasi organisasi, kecerdasan emosi dan pengambilan keputusan terhadap implementasi peran kepemimpinan kepala SD. Jurnal Akuntabilitas Manajemen Pendidikan, 2(2), 147-158.

Daud, F. (2012). Pengaruh kecerdasan emosional (EQ) dan motivasi belajar terhadap hasil belajar Biologi siswa SMA 3 Negeri Kota Palopo. Jurnal Pendidikan Dan Pembelajaran (JPP), 19(2), 243-255.

Dimyati, A. H. (2014). Model Kepemimpinan dan Sistem Pengambilan Keputusan. : CV Pustaka Setia.

Farida, S. I., \& Anjani, S. R. (2019). Menumbuhkan Jiwa Kepemimpinan Pada Mahasiswa di Lingkungan Universitas Pamulang. Jurnal Ilmiah Ilmu Manajemen INOVASI, 6(2), 19-20.

Goleman, D. (2003). Kecerdasan Emosional Untuk Mencapai Puncak Prestasi (alih bahasa, Alex Tri Kantjono). PT. Gramedia Pustaka Utama.

Handayani, E. (2020). Kepemimpinan Perempuan di Tangan Angka Survei. Timesindonesia. https://www.timesindonesia.co.id/read/news/261110/kepemimpinan-perempuan-ditangan-angka-survei

Herlina, H., \& Muhyani, M. (2018). Hubungan Pembinaan Orang Tua dan Pembinaan Siswa dengan Jiwa Kepemimpinan Siswa Di SMP Muhammadiyah 1 Bogor. Ta'dib: Jurnal Pendidikan Islam, 7(2), 23-32.

Jati, G. W., \& Yoenanto, N. H. (2013). Kecerdasan Emosional Siswa Sekolah Menengah Pertama Ditinjau dari Faktor Demografi. Jurnal Psikologi Pendidikan Dan Perkembangan, 2(2), 109-123. 
Komarudin, R. R. (2016). Meningkatkan Keterampilan Kepemimpinan Melalui Diskusi Kelompok Kecil (Buzz-Group) Pada Siswa SMA Kelas XI MIPA1 SMA Negeri 1 Pakem. Jurnal Riset Mahasiswa Bimbingan Dan Konseling, 5(1).

Kristianto, A. A., \& Fitriana, W. (2019). Latihan Kepemimpinan Melalui Kegiatan Ekstrakurikuler Pramuka (Studi kasus aktivis pramuka penegak di SMK Budi Bakti Utama). Comm-Edu (Community Education Journal), 2(2), 108-112.

Kuswara, R., Hartuti, P., \& Sinthia, R. (2018). Efektivitas Layanan Konseling Kelompok Teknik Modelling Dalam Membentuk Keterampilan Kepemimpinan Siswa. Jurnal Ilmiah Bimbingan Dan Konseling, 1(2).

Mahendra, E. I. W. 2017. (2017). Menemukan pengetahuan baru melalui penelitian ilmiah. Mengembangkan Kemampuar Research dalam Menghadapi Era SDGs. Lembaga Penelitian Dan Pengabdian Masyarakat (LPPM) IKIP PGRI Jember, Pp., 12-24.

Marpaung, M. (2014). Pengaruh kepemimpinan dan Team work Terhadap kinerja karyawan Di koperasi sekjen kemdikbud senayan jakarta. Jurnal Ilmiah WIDYA, 1(1).

Melianasari, D. (2016). Penerapan Layanan Bimbingan Kelompok Melalui Teknik Permainan Simulasi Dan Untuk Meningkatkan Kecerdasan Emosional Siswa. Pedagogis : Jurnal Pendidikan.

Mumford, T. V., Campion, M. A., \& Morgeson, F. P. (2007). The leadership skills strataplex: Leadership skill requirements across organizational levels. The Leadership Quarterly, 18(2), 154-166.

Nugraha, T. H., \& Pujiastuti, H. (2019). Analisis Kemampuan Komunikasi Matematis Siswa Berdasarkan Perbedaan Gender. Edumatica: Jurnal Pendidikan Matematika, 9(1), 17.

Oktiani, E., Hanifah, N., \& Aeni, A. N. (2017). Penerapan Metode Sosiodrama Bermedia Bando Desa Untuk Meningkatkan Hasil Belajar Dan Leadership Skill. Jurnal Pena Ilmiah, 2(1), 2041-2050.

Purwanti, K. L. (2013). Perbedaan Gender Terhadap Kemampuan Berhitung Matematika Menggunakan Otak Kanan Pada Siswa Kelas I. Sawwa. Jurnal Studi Gender, 9(1), 107-122.

Puspitawati, H. (2013). Konsep, teori dan analisis gender. Bogor: Departe-Men Ilmu Keluarga Dan Kon-Sumen Fakultas Ekologi Manusia Institut Pertanian.

Quamila, A. (2020). Siapa yang Lebih Baik Jadi Pemimpin: Pria atau Wanita? Hello Sehat. https://hellosehat.com/hidup-sehat/psikologi/pemimpin-yang-lebih-baik-pria-atauwanita/

Rahmasari, L. (2012). Pengaruh kecerdasan intelektual, kecerdasan emosi dan kecerdasan spiritual terhadap kinerja karyawan. Majalah Ilmiah Informatika, 3(1).

Rivai, V. (2004). Kiat Kepemimpinan dalam Abad ke 21. Murai Kencana.

Saputra, M. H. (2010). Kecerdasan Emosi dan Kecerdasan Spiritual Sebagai Faktor Pendukung Kepemimpinan Transformasional dan Perubahan Organisasional. SEGMEN Jurnal Manajemen Dan Bisnis, 1.

Setyawan, A. A., \& Simbolon, D. (2018). Pengaruh Kecerdasan Emosional Terhadap Hasil Belajar Matematika Siswa Smk Kansai Pekanbaru. JPPM (Jurnal Penelitian Dan Pembelajaran Matematika), 11(1). 
Sulistiyawati, S., \& Andriani, C. (2017). Kemampuan berpikir kritis dan hasil belajar biologi berdasarkan perbedaan gender siswa. WACANA AKADEMIKA: Majalah Ilmiah Kependidikan, 1(2).

Supriyanto, A. S., \& Troena, E. A. (2012). Pengaruh Kecerdasan Emosional dan Kecerdasan Spiritual terhadap Kepemimpinan Transformasional, Kepuasan Kerja dan Kinerja Manajer (Studi di Bank Syari'ah Kota Malang). Jurnal Aplikasi Manajemen, 10(4), 693-617.

Suryadi \& Nasution, M. (2019). Konseling Individual Untuk Mengatasi Perilaku Bullying Pada Perbedaan Gender Di MTs Negeri Sleman Maguwoharjo Yogyakarta. Jurnal Bimbingan \& Konseling Islam, 9(1), 54-67.

Utami, S. P. (2014). Hubungan Antara Kecerdasan Emosi Dan Budaya Organisasi Dengan Gaya Kepemimpinan Supervisi Produksi Di Pt. Faber Castell Indonesia. Jurnal Ilmiah Widya, 1(1). 